\title{
RELATIONSHIP BETWEEN MAXIMUM AEROBIC SPEED PERFORMANCE AND VOLLEYBALL GAME MOTOR POWER-EXPLOSIVE ABILITIES
}

\author{
Zerf M. ${ }^{1}$, Hadjar Kherfane M. ${ }^{2}$, Kohli K. ${ }^{3}$, Louglaib L. ${ }^{4}$ \\ 1, 2,3,4University Abdel Hamid Ibn Badis \\ Corresponding Author: Mohammed Zerf, e-mail: biomeca.zerf@outlook.com \\ Accepted for Publication: December 20, 2019 \\ Published: December 25, 2019
}

DOI:10.17309/tmfv.2019.4.03

\begin{abstract}
Purpose. This study aims to estimate the relevant maximum aerobic speed performance and its relationship with volleyball game motor power-explosive abilities. Shown in rugby and soccer science literature, maximal aerobic speed is considered as a critical factor for improving the athlete's ability to recover from high-intensity and fatiguing actions.

Materials and methods. To achieve this goal, we categorised the motor abilities (vertical jump, spike approach, block jump, 20-meter sprint, T-Test (agility) and standing triple jump) results of 60 elite male players (age $23 \pm 1.56$ with playing experience up to 5 years in the Oran elite leagues). We based ourselves on their MAS results in two levels (+ or $-4 \mathrm{~m} / \mathrm{s}$ ) in $1200 \mathrm{~m}$ Shuttle Test as a valuable test to measure player maximal aerobic speed profile.

Results. Our results approved the performance level of maximal aerobic speed archived at up to 4 (m/s) as the enhanced level directly related to notable levels of players' motor abilities studied in the present study. Conclusions. Our protocol of maximum aerobic speed performance confirmed level $4(\mathrm{~m} / \mathrm{s})$ as the relevant MAS level positively related to motor abilities components such as agility, balance, coordination, power, reaction, and speed, contrary to its lows.

Keywords: male, volleyball, elite, maximal aerobic speed, motor abilities, explosiveness.
\end{abstract}

\section{Introduction}

Considering that volleyball game is composed of short intervals of rapid and explosive movements, it requires the integrated development of flexibility, muscular strength, power and agility to increase the optimum skill performance for each player (Volleyball Alberta, 2017). Referenced by volleyball science literature as a skill-related fitness component of players' force, power output and jump abilities. Volleyball training studies adjudge working intermittently with a short recovery duration between continuous efforts as high-intensity efforts (Borozan, et al., 2016). Specific volleyball skill training involves the repetitions of intensive efforts (Datson, et al., 2014). Sustained by the similarities built on the athlete's ability to recover from high intensity and fatiguing actions. Estimated from data fitness testing results and the relative strengths and weaknesses of a player (Peev, et al., 2017) conjugated with skill-related fitness training programs. Such as

(C) Zerf M., Hadjar Kherfane M., Kohli K., Louglaib L., 2019. power, strength, speed, agility, and anaerobic fitness, agreeing to (Stamm et al., 2005). Rikberg \& Raudsepp (2011) revealed that the indicators of players' skill performance are the quality of the muscular fitness components of strength, power, agility, and speed. Challenging players to enhance their skill levels by repeating the motor acts in combination with their skill-related fitness energy demands (Pion, et al., 2015). Notified in basketball studies through aerobic and anaerobic profile of volleyball players that are similar to basketball players' demands. Requesting from volleyball players to develop their aerobic status above $100 \%$ of Maximal Aerobic Speed (MAS). Energy tolerance is documented in training studies as a critical key physiological skeletal muscle energy adaptation enabling players to repeat or maintain muscular contractions over-exercise time (Peev, et al., 2017). Subjected by the present study as a specific key adjustment of player technique referred to its component skill-related fitness developments (Ronald, 2009). Agreed by Andrzejewski, et al., (2015) via the player capacity to recover from high-intensity efforts or fatiguing actions in repeating game-related skills efforts 
at a high-level (Moraru and Radu., 2014). Investigated in this study build on the relevant MAS level and its relationships with volleyball, Alberta Test Protocols. It was assessed from Standing Reach, Vertical Jump Test (spike approach), Vertical Jump Test (block), T-Test (agility) and 20-meter sprint (V. A. O, 2017), additional to standing triple jump (TJ) as a valid test to assess players' coordination and leg strength (Suchomel, et al., 2016). They are known in similarities as useful tests to estimate anaerobic power related to power output and explosive activities (Buckworth, et al., 2013). This study suggests a pilot protocol to inspect the prominent MAS level which allows players to maximise their performance in explosive volleyball techniques such as jumping, acceleration or deceleration, blocking and spiking.

\section{Material and methods}

\section{Tests and protocol}

We used the tests of the Volleyball Alberta Testing Protocol (VAO) that includes:

- Standing Reach (VJ): measuring the vertical jump hight.

- Vertical Jump Spike approach (VJS): athletes should attempt to touch the vertical at the highest point of the jump (with one hand, like a volleyball spike).

- Vertical Jump Test Block (VJB): athletes should attempt to touch the vertical (with both hands like a block in volleyball).

- T-Test Agility (TA): the test includes 4 cones $(\mathrm{A}, \mathrm{B}, \mathrm{C}, \mathrm{D})$, cones $\mathrm{A}$ and $\mathrm{B}$ are $10 \mathrm{~m}$ apart, and cones $\mathrm{C}$ and $\mathrm{D}$ are $5 \mathrm{~m}$ from cone B. Following a warm-up, the athlete stands at cone $\mathrm{A}$ on the command, the athlete sprints to cone $B$ and touches the base of the cone with his/her hand and shuffles either to the left toward cone $\mathrm{C}$ or to the right toward cone $\mathrm{D}$ and touches the cone with the closest hand. The athlete faces forward at all time and cannot cross their feet. Upon touching cones $\mathrm{C}$ or $\mathrm{D}$, the athlete shuffles to the other far cone and touches it with the closest hand. The athlete does not touch cone B when crossing to the other side. The athlete shuffles back to cone $B$ and touches its base. The athlete runs backwards to cone $\mathrm{A}$, and at the moment he/she crosses the cone, the time is stopped.

- The 20 -meter sprint $(20 \mathrm{~ms})$ : the athlete is to sprint fast from one line to the finish line.

- According to Volleyball Alberta Coaching, all tests used to assess the athlete's anaerobic power are using speed as an indirect indicator (V. A. O, 2017).

For coordination, we applied the standing triple jump (TJ). Ashton (2013) supports the view that its phases (hop, steep, and jump) (Ashton, 2013) have a high correlation with coordination locomotion, according to Shepherd and Antoniades (2010).

Protocol. We use $1200 \mathrm{~m}$ Shuttle Test to classify the players under their MAS.

The $1200 \mathrm{~m}$ Shuttle Test was developed to measure an athlete's ability to run $1200 \mathrm{~m}$ quickly. It has been a valid and reliable predictor of high-intensity aerobic capacity and VO2 max in athletes from various sports and competition levels. To calculate Maximal Aerobic Speed, we used the formula:

MAS $(\mathrm{m} / \mathrm{s})=1200 /($ time in seconds for - BMI) (Shepherd and Antoniades, 2010).

Experience progress: all tests were held in 2 days, separated by 48 hours

- On the first day, we applied the $1200 \mathrm{~m}$ Shuttle Test, for the second, we practised the other tests. All participants passed the exams without difficulty (Paradisis, et al, 2014).

- On the second day, we followed the process made by Peev, et al. (2017):

- Bodyweight $(\mathrm{kg})$ and height $(\mathrm{cm})$ were measured using a digital scale calibrated against known weights to ensure its validity and reliability.

- Warm-up consists of 8-minute running; six minutes of exercises for the whole body; six minutes of stretching, three accelerations of $20 \mathrm{~m}$.

- First, we held the standing triple jump. The participant made three consequent jumps with 1 minute between them. After the same sequences, we made the other jump tests.

Table 1. Present homogeneity of samples in anthropometric parameters

\begin{tabular}{|c|c|c|c|c|c|c|c|c|}
\hline Indicator & MAS & $\mathbf{N}$ & Mean & S. D & $\mathrm{T}$ & $\mathrm{P} \leq 0.05$ & Levene & $\mathrm{P} \leq 0.05$ \\
\hline \multirow[t]{2}{*}{ Height } & $-4 \mathrm{~m} / \mathrm{s}$ & 38 & 175.81 & 1.75 & \multirow{2}{*}{1.01} & \multirow{2}{*}{0.17} & \multirow{2}{*}{0.16} & \multirow{2}{*}{0.84} \\
\hline & $+4 \mathrm{~m} / \mathrm{s}$ & 22 & 177.32 & 1.09 & & & & \\
\hline \multirow[t]{2}{*}{ Weight } & $-4 \mathrm{~m} / \mathrm{s}$ & 38 & 68.17 & 2.44 & \multirow{2}{*}{1.19} & \multirow{2}{*}{0.12} & \multirow{2}{*}{0.39} & \multirow{2}{*}{0.70} \\
\hline & $+4 \mathrm{~m} / \mathrm{s}$ & 22 & 67.15 & 2.30 & & & & \\
\hline \multirow[t]{2}{*}{ BMI } & $-4 \mathrm{~m} / \mathrm{s}$ & 38 & 22.89 & 2.09 & \multirow{2}{*}{0.79} & \multirow{2}{*}{0.46} & \multirow{2}{*}{0.92} & \multirow{2}{*}{0.33} \\
\hline & $+4 \mathrm{~m} / \mathrm{s}$ & 22 & 21.53 & 2.04 & & & & \\
\hline
\end{tabular}

MAS(M/s); BMI (kg/m2); Weight (kg); Height (cm) 
- After 12 minutes, we made the $20 \mathrm{~m}$ sprint with two attempts. Each attempt was separated by 6-8 minutes' recovery between them. The best attempt was considered. The participant ran alone (Peev, et al., 2017).

Sample: All participants are elite male volleyball players (ages 22 to 25 years, +5 years in elite championships) from Oran League, division one. They voluntarily agreed to participate in this study. Tested during Algerian Championship 2016-2017, after their precompetition period.

Their homogeneousness was calculated based on the Levene's test presented in Table 1.

\section{Statistical Analysis}

SPSS Statistics 19 (Chicago, Illinois, IBM, USA) processed all statistical analyses.

Descriptive analysis, mean and standard deviation were performed regarding anthropometric and fitness characteristics. Independent T-Test and Pearson's correlation were used to inspect the difference and relationship between the study's variables, additional to the Levene's test to inspect the homogeneity of participants maintained at two levels $(-4 \mathrm{~m} / \mathrm{s}$ and $4+\mathrm{m} / \mathrm{s})$. Experienced as a protocol to establish their relationships with motor abilities. Achieved in Vertical Jump; spike approach; block test; T-Test (agility); 20-meter sprint, and standing triple jump (TJ).

\section{Study Results}

The data from the tests and the evocative statistics are presented in Table 2. Referring to the study protocol design and statistics applied. Our results are based on the independent t-test. Maximum aerobic speed was confirmed $s$ a fundamental tool to predict player power and explosive capacity allied to demand volleyball game motor abilities experimented in this study. Records for the advantage of players with MAS improvement at level up to $4(\mathrm{~m} / \mathrm{s})$. The present investigation established it as the relevant level to raise the components of motor ability like agility, balance, coordination, power, reaction, and speed, in contrast to its lows. It was asserted in the actual study as a key anaerobic power level that enables the player to maximise their results via the tests experimented in this study. Bucthe Worthy et al. (2013) consider strength and anaerobic power as the essential motoric abilities that condition the competitive success and sports performance. Ronald and the IOC Medical Commission (2009) specified strength and power data tests estimated to monitor initial levels and strength changes in conjunction with training programs. Ronald (2009) reports that the relationships between force and velocity, force production and power output, motor recruitment and elastic energy improve the athletic capabilities of athletes. Philip et al. (2010) agree through the effective training method prescribed to enhance the initial player level-specific sport skills performance demands. It is mainly integrated by trainers to improve the kinematical time and space. Dynamic strength limits of motion structures (Thomas, 2003). The aerobic speed, maximal power, special awareness, change of direction and game-specific agility (Tudor, \& Michael, 2015). This study accounted for the advantage of volleyball players with $+4(\mathrm{~m} / \mathrm{s})$. Records as significant performance related to volleyball skill-related fitness tested in the present study.

Table 2. Present motor abilities according to protocol MAS levels used

\begin{tabular}{|c|c|c|c|c|c|c|c|c|}
\hline Indicator & MAS & $\mathbf{N}$ & Mean & S. D & $\mathbf{t}$ & $\mathrm{P} \leq \mathbf{0 . 0 5}$ & Levene & $\mathrm{P} \leq \mathbf{0 . 0 5}$ \\
\hline \multirow[t]{2}{*}{ MAS } & $-4 \mathrm{~m} / \mathrm{s}$ & 38 & 3.47 & 0.09 & 8.95 & 0.00 & 33.84 & 0.00 \\
\hline & $+4 \mathrm{~m} / \mathrm{s}$ & 22 & 4.29 & 0.54 & & & & \\
\hline \multirow[t]{2}{*}{$20 \mathrm{~ms}$} & $-4 \mathrm{~m} / \mathrm{s}$ & 38 & 2.92 & 0.24 & $4.1 \mathrm{~d} 3$ & 0.00 & 0.07 & 0.86 \\
\hline & $+4 \mathrm{~m} / \mathrm{s}$ & 22 & 2.11 & 0.27 & & & & \\
\hline \multirow[t]{2}{*}{ TJ } & $-4 \mathrm{~m} / \mathrm{s}$ & 38 & 6.26 & 3.11 & 3.40 & 0.00 & 0.08 & 0.92 \\
\hline & $+4 \mathrm{~m} / \mathrm{s}$ & 22 & 7.23 & 3.44 & & & & \\
\hline \multirow[t]{2}{*}{ VJ } & $-4 \mathrm{~m} / \mathrm{s}$ & 38 & 51.61 & 5.93 & 6.02 & 0.00 & 0.19 & 0.66 \\
\hline & $+4 \mathrm{~m} / \mathrm{s}$ & 22 & 56.41 & 6.63 & & & & \\
\hline \multirow[t]{2}{*}{ VJS } & $-4 \mathrm{~m} / \mathrm{s}$ & 38 & 50.42 & 5.85 & 7.04 & 0.00 & 0.15 & 0.75 \\
\hline & $+4 \mathrm{~m} / \mathrm{s}$ & 22 & 57.83 & 6.62 & & & & \\
\hline \multirow[t]{2}{*}{ VJB } & $-4 \mathrm{~m} / \mathrm{s}$ & 38 & 51.57 & 5.93 & 6.38 & 0.00 & 0.03 & 0.98 \\
\hline & $+4 \mathrm{~m} / \mathrm{s}$ & 22 & 57.52 & 6.85 & & & & \\
\hline \multirow[t]{2}{*}{ TA } & $-4 \mathrm{~m} / \mathrm{s}$ & 38 & 4.9 & 0.55 & 4.42 & 0.00 & 0.04 & 0.88 \\
\hline & $+4 \mathrm{~m} / \mathrm{s}$ & 22 & 4.06 & 0.62 & & & & \\
\hline
\end{tabular}

$\operatorname{MAS}(\mathrm{M} / \mathrm{s}) ; \mathrm{TJ}(\mathrm{m}) \mathrm{VJ}(\mathrm{cm}) \mathrm{VJS}(\mathrm{cm}) ; \mathrm{VJB}(\mathrm{cm}) ; \mathrm{TA}(\mathrm{s}) ; 20 \mathrm{~m}(\mathrm{~s})$ 
Table 3. Present correlation between MAS levels and players' level motor volleyball abilities tested.

\begin{tabular}{|c|c|c|c|c|c|c|}
\hline $\begin{array}{l}\text { MAS } \\
\text { Levels }\end{array}$ & $20 \mathrm{~ms}$ & TJ & VJ & VJS & VJB & TA \\
\hline$-4 \mathrm{~m} / \mathrm{s}$ & $+0.84^{\star *}$ & $-0.83^{\star \star}$ & $-0.84^{\star *}$ & $-0.82^{\star \star}$ & $-0.85^{\star *}$ & $+0.84^{\star \star}$ \\
\hline$+4 \mathrm{~m} / \mathrm{s}$ & $-0.94^{\star *}$ & $+0.92^{\star *}$ & $+0.94^{* *}$ & $+0.94^{\star *}$ & $+0.95^{\star *}$ & $-0.94^{* *}$ \\
\hline
\end{tabular}

**. The mean difference is significant at the 0.05 level.

Evoked by Kostikiadis et al. (2018) through adequate skill-based conditioning game training that simulates the relationship between physical characteristics and their skill-related fitness performance. Set up by the US National Strength \& Conditioning Association as a key method for improving muscle endurance and significant gains in aerobic and anaerobic power capacity (Kostikiadis, et al., 2018). Informed by volleyball studies built on specific volleyball condition programs, which include some additional resistance sprint and agility training (Stamm, et al., 2005), especially in mastering cycle or competition periods. Admitted by Rikberg, \& Raudsepp (2011), below complex and specific methods that increased anaerobic speed reserve positively associated with fatigue actions (Pion, et al., 2015). Outlined in the present study as fundamental skill-related fitness performance more positively interrelated with MAS +4 $(\mathrm{m} / \mathrm{s})$ than its lows, see Table 3.

\section{Discussion}

Our results confirmed MAS level $+4 \mathrm{~m} / \mathrm{s}$, as a vital anaerobic players' capacity combined with the highest result scored in the volleyball tests involved in this study. Supported in this study as the relevant level to raise the components of motor ability like agility, balance, coordination, power, reaction, and speed, in contrast to its lows. Paradisis, et al. (2014) supported it through the assessment of anaerobic energy. It was pointed out as a critical indicator of improvement in jump performance (Edward, 2012). In addition to their super values are better associated with higher vertical jump values and technical skills competency and proficiency (CristinaElenaa, \& Liliana-Elisabetaa, 2014). Admitted by Methenitis, et al., (2016) through the ability of players to recover from high-intensity and fatiguing actions. This study acknowledged MAS level $+4 \mathrm{~m} / \mathrm{s}$ as a prominent level of anaerobic capacity, permitting players to succeed in the short higher instance test or technique (Pion, et al., 2015). Specified by its significant relationships with the volleyball, Alberta Test Protocol. Certified in similarities as field tests qualified to estimate players' anaerobic power. Founding on speed as an indirect indicator (Shepherd, \& Antoniades, 2010). Rugby and soccer studies mentioned Maximal Aerobic Speed and its correlation with anaerobic speed reserve (Ferreira, et al., 2019) and systematic development of the anaerobic capacity. Shown by Peev, et al., (2017) via its relationships with technical (power tests or speed). As well as their associations with aerobic power, explosive strength, and motor performance, agreeing to Methenitis, et al, (2016). Piero (2016) confirmed the benefits of anaerobic fitness training, which is able to enhance muscle strength, power, hypertrophy, muscular endurance, and motor performance. Outlined in the present study by maximal aerobic speed developed by players at up to $4(\mathrm{~m} / \mathrm{s})$. It was revealed as prominent MAS levels, allowing players to increase their performance in explosive volleyball techniques, tested in the present study.

\section{Conclusions}

Our outcomes positively confirmed maximal aerobic speed developed by the volleyball player for up than $4(\mathrm{~m} / \mathrm{s})$ as a significant anaerobic status profile directly related to players technical skills and their demands physical capacity improvements. It was admitted in this study as a beneficial level and test strategy to predict motor abilities components like agility, balance, coordination, power, reaction, and speed, contrary to its lows. This study recommends it as a significant level that allows players to increase their performance in explosive volleyball techniques tested in the present study.

\section{Acknowledgements}

We are grateful to all players and their trainers, who accepted voluntarily to participate in this study. The authors are solely responsible for the design; collection, analysis, and interpretation of data; writing of the report; or the decision to submit the manuscript for publication.

\section{Financial support and sponsorship}

No financial support.

\section{Conflicts of interest}

There are no conflicts of interest.

\section{References}

Andrzejewski, M., Chmura, J., Pluta, B., \& Konarski, J. M. (2015). Sprinting Activities and Distance Covered by Top Level Europa League Soccer Players. International Journal of Sports Science and Coaching, 11(1), 39-50. https://doi.org/10.1260\%2F1747-9541.10.1.39

Ashton, M.C. (2013). Individual differences and personality. Amsterdam: Academic Press.

Buckworth J., Rod, K. D., Patrick, J. O'C., \& Phillip D. T. (2013). Champaign, IL: Human Kinetics.

Carlos Ayán-Pérez, José M. Cancela-Carral, Joaquín LagoBallesteros, Iván Martínez-Lemos. (2016). Reliability 
of Sargent Jump Test in 4- to 5-Year-Old Children. Perceptual and Motor Skills, 124(1), 39-57. https://doi. org/10.1177\%2F0031512516676174

Cristina-Elenaa M and Liliana-Elisabetaa R. (2014). Aspects regarding the level of coordination abilities in both athletes and non-athletes. Procedia - Social and Behavioral Sciences, 117, 162 - 166.

Datson N., Hulton A., Andersson H., Lewis T., Weston M., Drust B. and Gregson. (2014). Applied physiology of female soccer. Sports Medicine, 44(8), 1225-1240.

Duane V. K. (2007). Fundamentals of biomechanics. New York, NY: Springer.

Edward S. (2012). The science of volleyball practice development and drill design: from principles to applications. Bloomington, IN: iUniverse.

Ferreira, A., Enes, C., Leao, C., Goncalves, L., Clemente, F., Lima, R., Bezerra, P., \& Camoes, M. (2019). Relationship Between Power Condition, Agility, And Speed Performance Among Young Roller Hockey Elite Players. Human Movement, 20(1), 24-30. https://doi. org/10.5114/hm.2019.79040

Paradisis, G. P., Zacharogiannis, E., Mandila, D., Smirtiotou, A., Argeitaki, P., \& Cooke, C. (2014). Multi-Stage 20-m Shuttle Run Fitness Test, Maximal Oxygen Uptake and Velocity at Maximal Oxygen Uptake. Journal of Human Kinetics, 41(1), 81-87. https://doi.org/10.2478/ hukin-2014-0035

Haugen, T. A., Tønnessen, E., Hem, E., Leirstein, S., \& Seiler, S. (2014). VO2max characteristics of elite female soccer players, 1989-2007. Int J Sports Physiol Perform., 9(3), 515-21. https://doi.org/10.1123/ijspp.2012-0150

Borozan, I., Grădinaru, S., Miron, P., Puta, T., \& Bota, E. (2016). Postural differences of volleyball players. Timisoara Physical Education and Rehabilitation Journal, 9(17), 42-46. https://doi.org/10.1515/tperj-2016-0014

Kostikiadis, I.N., Methenitis, S., Tsoukos, A., Veligekas, P., Terzis, G., \& Bogdanis, G.C. (2018). Effect of ShortTerm Sport-Specific Strength and Conditioning Training on Physical Fitness of Well-Trained Mixed Martial Arts Athletes. J Sports Sci Med, 17(3), 348-358. Retrieved from https://www.ncbi.nlm.nih.gov/pubmed/30116107

Methenitis, S. K., Zaras, N. D., Spengos, K. M., Stasinaki, A.-N. E., Karampatsos, G. P., Georgiadis, G. V., \& Terzis, G. D. (2016). Role of Muscle Morphology in Jumping, Sprinting, and Throwing Performance in Participants With Different Power Training Duration
Experience. The Journal of Strength \& Conditioning Research, 30(3), 807-817. https://doi.org/10.1519/ JSC.0000000000001147

Peev, P. (2017). Metodicheskipodhodi za vuzdeistvievarhuskorostnata izdrajlivost pri 13-14 godishnifutbolisti. Sofia PhD thesis, 167.

Peev, P., Tsvetkov, S., \& Gadev, M. (2017). Reliability of the field test " $3 \times 50 \mathrm{~m}$ shuttle to determine anaerobic power with football players aged 13-14. Research in Kinesiology and Other Related Sciences, 1(40), 105-108.

Philip, M., \& Mark, A. (2010). The big book of endurance training and racing. New York: Skyhorse Pub.

Piero, V. (2016). Arthroscopy and Sport Injuries: Applications in High-level Athletes. Cham: Springer.

Pion, J. A., Fransen, J., Deprez, D. N., Segers, V. I., Vaeyens, R., Philippaerts, R. M., \& Lenoir, M. (2015). Stature and Jumping Height Are Required in Female Volleyball, but Motor Coordination Is a Key Factor for Future Elite Success. The Journal of Strength \& Conditioning Research, 29(6), 1480-1485. https://doi.org/10.1519/ JSC.0000000000000778

Rikberg, A., \& Raudsepp, L. (2011). Multidimensional Performance Characteristics in Talented Male Youth Volleyball Players. Pediatric Exercise Science, 23(4), 537 548. https://doi.org/10.1123/pes.23.4.537

Ronald, J. M. (2009). The Olympic Textbook of Science in Sport. Chichester, UK; Hoboken, NJ: Wiley-Blackwell.

Shepherd, J., \& Antoniades, M. (2010). 101 youth fitness drills: age 7-11. London: A \& C Black.

Stamm, R., Stamm, M., \& Thomson, K. (2005). Role of adolescent female volleyball players' psycho-physiological properties and body build in performance of different elements of the game. Percept Mot Skills, 101(1), 108120. https://doi.org/10.2466/pms.101.1.108-120

Thomas, R. (2003). Advances in Sport, Leisure and Ergonomics. London: Routledge.

Suchomel, T.J., Nimphius, S. \& Stone, M.H. (2016). The Importance of Muscular Strength in Athletic Performance. Sports Medicine, 46(10), 1419-1449. https://doi. org/10.1007/s40279-016-0486-0

Tudor, B., \& Michael, C. (2015). Conditioning young athletes. Champaign, IL: Human Kinetics.

Volleyball Alberta (2017). Volleyball Alberta Testing Protocol. Retrieved 5 6, 2017, from Volleyball Alberta Coaching: http://www.volleyballalberta.ca/sites/default/files/sites/Indoor/Team_AB/VA\%20Testing\%20 Protocols\%20-15.pdf 


\title{
ВЗАЄМОЗВ'ЯЗОК МІЖ ПОКАЗНИКАМИ МАКСИМАЛЬНОЇ АЕРОБНОЇ ШВИДКОСТІ ТА РУХОВИМИ ВИБУХОВО- СИЛОВИМИ ЗДІБНОСТЯМИ У ВОЛЕЙБОЛІ
}

\author{
Зерф М. ${ }^{1}$, Хадіяр Херфане М. ${ }^{2}$, Кохлі К. ${ }^{3}$, Луглаїб Л. ${ }^{4}$ \\ 1,2,3, 4Університет Абдель Хамід Ібн Бадіс \\ Реферат. Стаття: 5 с., 3 табл., 27 джерело.
}

Мета дослідження - оцінити відповідні показники максимальної аеробної швидкості та їх зв'язок з руховоми вибухово-силовими здібностями у волейболі. Дані наукової літератури 3 регбі та футболу дозволили вважати максимальну аеробну швидкість вирішальним фактором для покращення здатності спортсмена відновлюватися після високоінтенсивних та виснажливих тренувань.

Матеріали і методи. Для досягнення цієї мети ми класифікували результати рухових здібностей (вертикальний стрибок, атакуючий підхід, блокуючий стрибок, 20-метровий спринт, Т-тест (спритність) та потрійний стрибок 3 місця) 60 висококласних гравців-чоловіків (вік $23 \pm 1.56$ д досвідом гри до 5 років у елітних лігах Орану). Аналізувалися ix показники максимальної аеробної швидкості на двох рівнях (+ або - 4 м/с) у тесті «Човниковий біг 1200 м», який $€$ ефективним тестом для вимірювання максимальної аеробної швидкості гравця.

Результати. Наші результати підтвердили, що рівень максимальної аеробної швидкості до 4 (м/с) $\epsilon$ високим рівнем, безпосередньо пов'язаним зі значними рівнями рухових здібностей гравців, розглянутих у цьому дослідженні.

Висновки. Наш протокол показників максимальної аеробної швидкості підтвердив рівень 4 (м/с) як відповідний рівень максимальної аеробної швидкості, позитивно пов'язаний з такими компонентами рухових здібностей як спритність, рівновага, координація, сила, реакція та швидкість, на відміну від нижчих рівнів.

Ключові слова: чоловіки, волейбол, максимальна аеробна швидкість, рухові здібності.

\section{ВЗАИМОСВЯЗЬ МЕЖДУ ПОКАЗАТЕЛЯМИ МАКСИМАЛЬНОЙ АЭРОБНОЙ СКОРОСТИ И ДВИГАТЕЛЬНЫМИ ВЗРЫВНО- СИЛОВЫМИ СПОСОБНОСТЯМИ В ВОЛЕЙБОЛЕ}

\author{
Зерф М. ${ }^{1}$, Хадияр Херфане М. ${ }^{2}$, Кохли К. ${ }^{3}$, Луглаиб Л. ${ }^{4}$ \\ 1, 2, 3, 4Университет Абдель Хамид Ибн Бадис \\ Реферат. Статья: 5 с., 3 табл., 27 источник.
}

Цель исследования - оценить соответствующие показатели максимальной аэробной скорости и их связь с двигательными взрывными силовыми способностями в волейболе. Данные научной литературы по регби и футболу позволили считать максимальную аэробную скорость решающим фактором для улучшения способности спортсмена восстанавливаться после высокоинтенсивных и изнурительных тренировок.

Материалы и методы. Для достижения этой цели мы классифицировали результаты двигательных способностей (вертикальный прыжок, атакующий подход, блокирующий прыжок, 20-метровый спринт, Т-тест (ловкость) и тройной прыжок с места) 60 высококлассных игроков-мужчин (возраст $23 \pm 1.56$ с опытом игры в 5 лет в элитных лигах Орана). Анализировались их показатели максимальной аэробной скорости на двух уровнях (+ или -4 м/с) в тесте «Челночный бег 1200 м», который является эффективным тестом для измерения максимальной аэробной скорости игрока.

Результаты. Наши результаты подтвердили, что уровень максимальной аэробной скорости до 4 (м/с) является высоким уровнем, непосредственно связанным со значительными уровнями двигательных способностей игроков, рассмотренных в этом исследовании.

Выводы. Наш протокол показателей максимальной аэробной скорости подтвердил уровень $4(\mathrm{M} / \mathrm{c})$ как соответствующий уровень максимальной аэробной скорости, положительно связан с такими компонентами двигательных способностей как ловкость, равновесие, координация, сила, реакция и скорость, в отличии от низших уровней.

Ключевыеслова: мужчины, волейбол,максимальная аэробная скорость, двигательные способности. 


\section{Information about the authors:}

Zerf Mohammed: biomeca.zerf@outlook.com; https://orcid.org/0000-0001-5013-5446; Institute of Physical Education and Sports, University Abdel Hamid Ibn Badis, Mostaganem, Algeria.

Kherfane Mohammed Hadjar: mohadjar@hotmail.com; https://orcid.org/0000-0003-3353-6154; Institute of Physical Education and Sports, University Abdel Hamid Ibn Badis, Mostaganem, Algeria.

Kohli Kamel: kamel.76@live.com; https://orcid.org/0000-0002-5675-1829; Institute of Physical Education and Sports, University Abdel Hamid Ibn Badis, Mostaganem, Algeria.

Louglaib Lakhdar: lakhdar.louglaib@univ-mosta.dz; https://orcid.org/0000-0003-3245-0981; Institute of Physical Education and Sports, University Abdel Hamid Ibn Badis, Mostaganem, Algeria.

Cite this article as: Zerf, M., Hadjar Kherfane, M., Kohli, K., \& Louglaib, L. (2019). Relationship Between Maximum Aerobic Speed Performance and Volleyball Game Motor Power-Explosive Abilities. Teoriâ ta Metodika Fizičnogo Vihovannâ, 19(4), 179-185. https://doi.org/10.17309/tmfv.2019.4.03

Received: 20.11.2019. Accepted: 20.12.2019. Published: 25.12.2019

This work is licensed under a Creative Commons Attribution 4.0 International License (http://creativecommons.org/ licenses/by/4.0). 